\title{
THE NEXUS BETWEEN FIRM SPECIFIC FACTORS, MACROECONOMIC FACTORS AND FIRM PERFORMANCE OF TEXTILE SECTOR OF BANGLADESH
}

\author{
Imran Mahmud \\ Independent Researcher \\ Faculty of Business Studies \\ University of Dhaka, Dhaka, Bangladesh \\ E-mail: Imran.mahmud.du@gmail.com \\ Hossain Ahmmed Fahad \\ Independent Researcher \\ Faculty of Business Studies \\ University of Dhaka, Dhaka, Bangladesh \\ E-mail: Fahadhossain.frg@gmail.com \\ Atkia Nabiha Rahman \\ Independent Researcher \\ Faculty of Business Studies \\ University of Dhaka, Dhaka, Bangladesh \\ E-mail: A.nabiharahman@gmail.com
}

\begin{abstract}
The purpose of this study is to identify the determinant factors of the profitability of textile sector of Bangladesh. To achieve this, a sample of 31 textile companies for the period of 2011 to 2019 is used. Two dependent variables- return on assets ROA (accounting measure) and Tobin's $Q$ (market measure) are tested using both fixed effect model and Panel corrected standard error (PCSE) model. As the PCSE regression robustly suited the dataset, this is used to explain the impact of both firm specific factors and macro-economic factors on the performance of textile firms listed in Dhaka Stock Exchange. The determinants of profitability differ depending on which measures of profitability we have taken as proxy. When ROA is taken, age, debt to equity, debt to asset, growth, asset turnover, cost effectiveness (EATC) and export growth are found significant. Among them, debt to equity, asset turnover, cost effectiveness and export growth conforms to the expected positive sign. In terms of Tobin's $Q$, age, size, debt to equity, growth, cost effectiveness (EATC), board size and export growth are found having significant impact on firm performance where age, EATC, board size, and export growth conforms to the expected positive sign.
\end{abstract}

Keywords: Tobin's Q, Cross Sectional Dependence, Panel Data Analysis, PCSE Model, Textile Sector.

JEL Classification Codes: C83, C87, L25. 


\section{INTRODUCTION}

The economic growth and profitability of an industry contributes to the ultimate social welfare (Hermelo \& Vassolo, 2007). Firm performance plays an important role in national economic growth and creation of employment in the country. Bangladesh is a South Asian country with a population of approximately 165 million. Textile as a whole is a heterogeneous product market with yarn, fabric, colors, brands, fashion, and material quality etc. all contributing to create economic value. Readymade garments (RMG) sector of our country has become one of the biggest earners of foreign currency. Billions of dollars as export earnings are received and millions of jobs are created by this sector each year. This sector comprises for $83 \%$ of total export earnings with a value of \$33674 million during financial year 2019-2020.

Growth in the textile sector can be prolonged through the active role of both private and public stakeholders. The variables that influence the textile sector and its performance should be identified so that policymakers can formulate policies to influence those factors to have significant positive impact on textile firm's performance.

One of the intriguing discussions in business economics is regarding the determinant factors that impact firms' performance, comparing firm-specific as well as industry specific factors (Hintošová et al., 2020). There have been undeniable dominant opinions that choose firm specific factors over industrial factors to explain firm's performance (Blažková \& Dvouletý, 2018). In the light of resource-based theory, this study will focus in firm specific factors and macro-economic factors that influence the performance of textile sector. There are large empirical studies in this field around the world, however, few comparable works are conducted in Bangladesh. Kalam and Utsho (2020) had conducted a similar study to identify the impact of firm specific factors on the profitability of NBFI in Bangladesh using a panel data model. Islam and Khan (2019) investigated the factors affecting the firm's performance of pharmaceutical industry of Bangladesh using a random effect analysis. But with regard to textile industry, there exist only few studies conducted.

Hence, the goal of this paper is to assess the influence of firm-specific and macro-economic factors on the performance of firms operating in the Textile industry and thus to enrich the standing literature in this field. A firm-level panel dataset allows us to test the effect of selected factors on firms' performance using panel data regression approach of Fixed effect model and Panel Corrected Standard Error linear regression model.

The rest of the paper is designed as follows- section 2 is the literature review and hypothesis, section 3 contains the methodology, section 4 contains estimation and results, section 5 discussion of the result, section 6 represents comparison of result with previous studies and section 7 provides the conclusions.

\section{LITERATURE REVIEW}

Two competing approaches seeking to explain firm performance have been segmented into the industrial theory approach (Competitive forces approach) and resource-based approach. Significant works on the debate of industry effects versus firm-specific effects as key performance indicator have led other researchers to provide a more in-depth view on the issue (Rumelt, 1991; Porter, 1980; Schumacher \& Boland, 2005; Blažková \& Dvouletý, 2018; Hanggraeni et al., 2019). McGahan and Porter (2002), using a broad dataset covering every sector within the USA, showed that firm-specific factors influence business long run and short run profitability significantly in contrast to industrial factors. The study also showed that the effects of firm-specific individual factors have differed across different sectors. Another study was done by Pervan et al. (2018) illustrated that both firm-specific factors and industrial and macro-economic factors significantly 
affect business performance but the impact of the former was shown to be greater. The resourcebased view theory can be used to explain the importance of individual internal firm-specific factors in a firm's profitability (Barney, 1991). The theory is based on the premise that scarce resources that competitors cannot easily copy or imitate or substitute lead to superior performance.

Many studies have been conducted to identify firm-specific and macro-economic determinants in different countries in different sectors. Variables such as size, tangibility, growth, leverage level, liquidity ratio, and efficiency ratios are examined in studies to deal with internal determinants of firm performance with often inconclusive results. A pioneering study done by Chowdhury and Amin (2007) illustrated that working capital has a significant impact on the financial performance of pharmaceutical firms in Bangladesh. Kuntluru et al. (2008) conducted a study on the determinants of financial performance of Indian companies and found a negative relationship between debt ratio and profitability along with a positive relationship among firm size and growth and profitability. Stierwald (2010) took 961 large Australian firms and exhibited that lagged profit and firm size have the most contribution to performance and profitability. Pathirawasam (2011) found out that internal factors i.e., firm size, inventory ratio, debt ratio, and the quick ratio have a significant impact on the financial performance when measured by return on assets (ROA). The study of Pratheepan (2014) found out that size has a positive impact whereas leverage and liquidity have an insignificant impact on the profitability of manufacturing firms in Sri Lanka.

Bhutta and Hasan (2013) studied the firm-specific and macroeconomic factors on firm performance of food sector in Pakistan using multivariate regression analysis from 2002 through 2006. Findings revealed a significant negative impact of size and profitability on firm performance. Moreover, tangibility, growth, and food inflation are observed to have an insignificant positive impact and debt to equity an insignificant negative impact.

Chhapra et al. (2012) studied the determinants of capital structure that affect the growth of firms of Textile Sector in Pakistan using data from 90 companies from 2005 to 2010. They used a linear regression model to examine how size, taxes, profitability, fixed assets have an impact on financial leverage. They found that fixed assets, sizes, taxes, and net profit do not have any significant impact on leverage, however, the size of the firm has a negative significant impact on leverage.

Abbas et al. (2013) used leverage, growth, size, etc. as firm-specific factors to determine their impact on the profitability of the Textile sector of Pakistan. They used panel data of different firms for the period 2005 to 2010 using a linear regression model. Findings of the study exhibited that leverage has negative while the size of the firm has a positive impact on the firm's profitability. However, they failed to find any significant relationship of growth and liquidity on a firm's performance.

Antoun et al. (2018) studied the relationship of financial performance with internal and external factors on a sample selected from banks in Central and Eastern Europe. They found that size, bank concentration, economic growth, business mix, inflation rate can significantly explain financial performance when measured with a performance index. Jelena et al. (2018) in their study on the determinants of profitability of medium and large agricultural companies in Serbia concluded that market share, sales revenue growth, insurance, export, and current ratio have a positive impact on firm performance.

Blažková and Dvouletý (2018) conducted a study to investigate the impact of firm-specific factors on the financial performance of the Czech food processing firm over 2003-2014 with 1804 firms. The proxy for financial performance was taken as price-cost margin, return on assets and 
return on equity. They found a positive relationship between labor productivity and profitability, a negative relationship between leverage and profitability, and a positive relationship between age and firm size.

An exploratory study on the impact of firm-specific factors on profitability of life insurance companies in eight Asian countries covering a period of 2008-2014 using a panel data Random Model revealed that size, the volume of capital, and underwriting risk has a significant relationship with profitability. Besides, they found that premium growth, asset tangibility, and liquidity are insignificant indicators of profitability (Zainudin et al., 2018).

Vieira et al. (2019) performed a similar type of study on determinants of the Portuguese firms' performance. The study covered 37 non-financial firms from 2010 to 2015. They tested three dependent variables using the Generalized Method of Moments. They found that in terms of the market variable of performance, firm-specific variables are not so important to explain. They also explained that investor sentiment and insider ownership more effectively explain firm performance. They ultimately infer that determinant of firm performance change in compliance with the way stakeholders define firm performance. Dakić et al. (2019) implemented a study on the determinants of business success of Serbian Food Processing companies. The findings showed that debt ratio, quick ratio, sales growth, firm size, and capital turnover ratio can affect firm performance when measured by return on assets (ROA).

Hintošová et al. (2020) used age, liquidity ratio, size, asset turnover, and cost-effectiveness as determinants of firm profitability on data from 2009 to 2017 for 48 firms in the metallurgical industry in Slovakia and found a significant ambiguous impact of liquidity and age, negative impact of asset turnover and positive effect of cost-effectiveness on firm's profitability.

Ullah et al. (2020) conducted a similar study to determine the nexus between firm-specific, macroeconomic factors on the performance of the textile sector in Pakistan. The study was done on 90 textile firms for the period 2008 to 2017 forming unbalanced panel data. They found a negative significant impact of debt to equity, negative insignificant impact of asset turnover ratio, the positive impact of export growth and sales growth, and negative impact of firm size, tax payable, and debt to asset with insignificant impact on firm performance.

Kalam and Utsho (2020) in their study on firm-specific profitability indicators of the NBFIs in Bangladesh conducted a panel data analysis on 19 NBFIs from 2007 to 2017. The study used total interest income to total asset, non-operating income to total asset, operating expense to total asset, deposit to total asset, size, and Equity multiplier as explanatory variables and found mixed results about the significance and direction of the relationship.

Liu et al. (2020) undertook a study to identify the determinants of financial performance of agricultural companies in China with a data set of 39 listed companies for the period 2013-2018. The study tested internal firm-specific factors and external macro-economic factors where they have measured financial performance based on return on assets (ROA), return on sales (ROS), and return on equity (ROE). The results show that firm size, long term liability ratio, sales growth rate is positively related and debt ratio, capital intensity, and export intensity are negatively related to firm performance. Moreover, they found no significant impact of external factors on financial performance.

Islam and Khan (2019) published their work on determining the factors of profitability of pharmaceutical industry of Bangladesh using a Random Effect analysis. They used a sample size of 20 listed companies for a period 2007 to 2016. They found that sales, operating income, operating cost, return on equity, and total debt have a significant impact on profitability of 
pharmaceutical industry. They also found that in terms of macro-specific variables, GDP rate of inflation have a significant impact on firm performance.

\section{RESEARCH QUESTION}

- Is there any relationship between firm-specific factors and firm performance of the textile sector of Bangladesh?

- Is there any relationship between macro-economic factors and firm performance of the textile sector of Bangladesh?

\section{Sample Selection}

\section{METHOD}

We determined the appropriate sample size for a small population using the Cochran's formula (Glen, 2021).

1st step: determine the sample size for a larger population.

$n_{0}=\frac{Z^{2} p q}{e^{2}}$

Where, $\mathrm{n}_{0}=$ size of sample for a large population; $\mathrm{z}=$ the value at a certain confidence interval found in the $\mathrm{Z}$ table; $\mathrm{p}=$ estimated proportion of the population, that is, the sample; $\mathrm{q}=1-\mathrm{p}$. If $\mathrm{z}=$ 1.64 at $10 \%$ significance level, $\mathrm{p}=0.5$ so $\mathrm{q}=0.5$, the sample size would be, $\mathrm{n}_{0}=\frac{\mathbf{1 . 6 4}^{2} * \mathbf{0 . 5} * \mathbf{0 . 5}}{\mathbf{0 . 1}^{\mathbf{2}}}=67.24$ Step 2: determine the required sample size for a small population

$\boldsymbol{n}=\frac{\boldsymbol{n}_{\mathbf{0}}}{\mathbf{1}+\frac{\left(\boldsymbol{n}_{\mathbf{0}}-\mathbf{1}\right)}{N}}$

Where, $\mathrm{n} 0$ is Cochran's appropriate sample size, $\mathrm{N}$ is the population and $\mathrm{n}$ are the adjusted sample size for the population in this study.

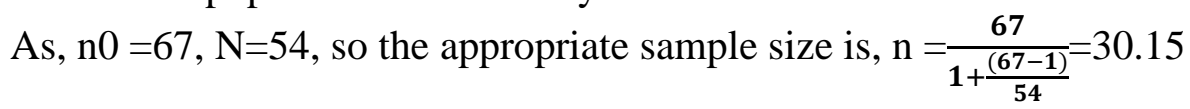

\section{Variables Selection}

\section{Dependent Variables}

As there is no clear literature or view on which variables should be taken as the proxy of firm performance, we have considered two dependent variables.

One Accounting Measure: In this study, we have defined financial performance, the dependent variable, by using return on total assets (ROTA). ROTA is also known as Basic Earning Power Ratio (BEP) ratio. This variable has been adopted in former research as well (Ahmad et al., 2015; Hintošová et al., 2020; Hult et al., 2008; Mijić et al., 2014; Bayaraa, 2017; Kumari \&Kumar, 2018; Fiala et al., 2020).

One Market Performance Measure: Tobin's Q has been taken as a proxy for firm performance in its competitive market. Tobin's Q is the modified version of q suggested by Chung and Pruitt (1994). According to the methodology of Singh et al. (2017), Tobin's Q is calculated by dividing the summation of the firm's market value of equity and total debt by the book value of total assets.

\section{Independent Variables}

The determinants of financial performance have been tested using firm-specific and macroeconomic specific predictors. Firm size, age, debt to equity (DE), debt to asset (DA), current ratio, 
board size, growth, asset turnover ratio, earning after tax as \% of total cost (EATC) are the representative of firm specific factors whereas taxation, GDP and export growth is selected as macro-economic factors.

The first variable is size of the firm. Most studies have proved that larger firms have higher profit generating ability thus showed a positive impact on financial performance (Asimakopoulus et al., 2009; Nunes et al., 2009; Pratheepan, 2014; Nakatani, 2019, Abbas et al., 2013; Majumdar \& Chhibber, 1999; Hermelo \& Vassolo, 2007). Goddard et al. (2005) however found a negative size-profitability relationship.

Age of the firm as a determinant factor is supposed to have bi-directional impact on firm performance (Coad et al., 2013; Blažková \& Dvouletý, 2019). They found that aging firm boosts productivity level and higher profits but slow down business performance. Cowling et al. (2018) on the other hand gathered proof of negative firm age-profitability relationship.

Current ratio is taken as a proxy for liquidity from the work of (Nanda \& Panda, 2018; Jelena et al., 2018). Liquidity is found to be positively related to profitability (Goddard et al., 2005; Nanda \& Panda, 2018; Yameen et al., 2019) as well as none or negatively related to profitability (Zainudin et al., 2018).

Asset turnover ratio, calculated by total sales to total assets, if higher indicates firm is efficiently using its assets to generate revenue. Ahmad et al. (2015) found a positive relationship between asset turnover ratio and profitability. Growth is measured as annual growth in assets following the work of Abbas et al. (2013) and Glancey (1998). Where Jelena et al. (2018) and Singh et al. (2019) found positive impact of growth, however, Ahmad et al. (2015) found a negative impact of growth on firm performance.

Within the resource-based view theory, it is said that manufacturing capabilities are generated internally which is inimitable non-transferable (Chavez et al., 2017). To incorporate this view, cost effectiveness has been taken as a determinant variable. Earning after tax as a \% of total cost (EATC) has been taken as a proxy for cost effectiveness. Hintošová et al. (2020) found a positive relationship between EATC and profitability.

Board of directors are responsible to protect shareholders' interest by restricting conflicts of interest between managers and shareholders. Guest (2009) and Marcelo et al. (2014) conducting a study on UK firms and Portuguese firms respectively found out that board size has a significant negative impact on profitability suggesting a weak monitoring and malfunction of boards' advisory role. On the other hand, Daily et al. (2003) and Drobetz et al. (2004) concluded a positive board size-profitability relationship.

Another important factor is leverage. To calculate leverage, debt to assets and debt to equity will be used following the methodology of Ullah et al. (2020). Most empiral studies have found an inverse leverage-profitability relationship (Asimakopoulus et al., 2009; Nunes et al., 2009; Khaled \& Samman, 2015; Nanda \& Panda, 2018; Blažková \& Dvouletý, 2019).

Taxation is calculated as income tax expense over earnings before taxes (EBT) following the methodology of Ullah et al. (2020). According to trade-off theory, the effective tax rate and profitability has a significant positive relationship as higher tax rate reduces the debt costs. Chhapra et al. (2012) found an insignificant relationship between tax and financial leverage whereas Ullah et al. (2020) found a significant negative relationship between profitability and tax rate.

Export is found to be positively related to firm performance of agricultural companies from the study of Jelena et al. (2018). Ullah et al. (2020) also found a significant positive export- 
profitability relationship on the textile firms of Pakistan. Natural logarithm of export growth has been taken as proxy of for this variable.

The last macro-economic variable selected for the study is real GDP. Bangladesh is speeding up with competition in regards of GDP. Gan et al. (2006) and Kosmidou (2008) found a positive relationship between GDP and performance.

Table 1. Definition of Variables Used in Study

\begin{tabular}{|c|c|c|c|}
\hline Variables & Notations & Description & Expected Sign \\
\hline \multicolumn{4}{|c|}{ Dependent Variables } \\
\hline \multirow{2}{*}{ Profitability } & ROA & Ratio of Net EBIT to Total Assets & \\
\hline & Tobin's Q & Ratio of (MVE +Debt) to Total Assets & \\
\hline \multicolumn{4}{|c|}{ Independent Variables } \\
\hline Control & Age & $\begin{array}{l}\text { Difference Between Year of Establishment and } \\
\text { the Year in Consideration }\end{array}$ & + \\
\hline \multirow{8}{*}{ Firm Specific } & Ln_Size & Logarithm of Total Assets & + \\
\hline & $\mathrm{DE}$ & Ratio of Interest bearing Debt to Total Equity & $-/+$ \\
\hline & DA & Ratio of Interest Bearing Debt to Total Assets & $-1+$ \\
\hline & TATO & Ratio of Total Sales to Total Assets & + \\
\hline & Growth & Annual Growth in Assets & + \\
\hline & Liquidity & Ratio of Current Asset to Current Liabilities & + \\
\hline & EATC & Earnings After Taxes as a Ratio of Total Costs & + \\
\hline & Board Size & Natural Logarithm of Board Size & + \\
\hline \multirow{3}{*}{ Macro-Economic } & Export Growth & $\begin{array}{l}\text { Variation in the Natural Logarithm of Total } \\
\text { Exports (Textile Sector). }\end{array}$ & + \\
\hline & Taxation & $\begin{array}{l}\text { Ratio of Income Tax Expenses Over Income } \\
\text { Earned Before Taxes (EBT) }\end{array}$ & + \\
\hline & Real GDP & Nominal GDP Less Inflation Rate & + \\
\hline
\end{tabular}

Note: ROA: Return on Total Asset; EBIT: Earnings Before Interest Tax; MVE: Market Value Equity; Ln: Natural Logarithm; DE: Debt-Equity; DA: Debt-Asset; TATO: Total Asset Turnover; EBT: Earnings Before Tax; GDP: Gross Domestic Product.

\section{Hypotheses}

Based on the literature review, the major policy questions of this paper is to identify how various predictor determinants affects the firm's performance of textile sector in Bangladesh and whether these factors have positive or negative impact on performance. Incidentally, the hypotheses to be tested are given as follows:

\section{Firm Specific factors}

- $\mathrm{H}_{0}$ : Firm size has no impact on firm's profitability

- $\mathrm{H}_{0}$ : Firm age has no impact on firm's profitability

- $\mathrm{H}_{0}$ : Debt to equity has no impact on firm's profitability

- $\mathrm{H}_{0}$ : Debt to asset has no impact on firm's profitability

- $\mathrm{H}_{0}$ : Asset turnover ratio has no impact on firm's profitability

- $\mathrm{H}_{0}$ : Growth has no impact on firm's profitability

- $\mathrm{H}_{0}$ : liquidity has no impact on firm's profitability

- $\mathrm{H}_{0}$ : Earning after tax as a \% of total cost has no impact on firm's profitability

- $\mathrm{H}_{0}$ : Board size has no impact on firm's profitability

Macro-economic factors

- $\mathrm{H}_{0}$ : Export has no impact on firm's profitability 
- $\mathrm{H}_{0}$ : Taxation has no impact on firm's profitability

- $\mathrm{H}_{0}$ : GDP has no impact on firm's profitability

\section{Model of the Study}

Using the determinants selected, the models that are germane to this study to analyze the hypothesized relationship between dependent and independent variable are-

$\mathrm{ROA}=\alpha+\beta 1$ Ageit $+\beta 2 \ln$ Sizeit $+\beta 3$ DEit $+\beta 4$ DAit $+\beta$ CRit $+\beta 6$ Growthit $+\beta$ 7TATOit + $\beta$ 8EATCit $+\beta$ 9Taxationit $+\beta 10$ Ex_growthit $+\beta 11$ BoardSizeit $+\beta 12$ GDPit + uit + eit

Tobin's $\mathrm{Q}=\alpha+\beta 1$ Ageit $+\beta 2 \ln$ Sizeit $+\beta 3$ DEit $+\beta 4$ DAit $+\beta 5$ CRit $+\beta 6$ Growthit $+\beta$ TATOit + $\beta 8$ EATCit $+\beta$ TTaxationit $+\beta 10$ Ex_growthit $+\beta 11$ BoardSizeit $+\beta 12$ GDPit + uit $+\varepsilon$ it

Where $\mathrm{i}=1,2, \ldots \mathrm{n}$ and $\mathrm{t}=1,2, \ldots \mathrm{t}$ representing firm and year respectively; $\beta$ is the parameter and $\varepsilon$ represents the error term or disturbance and $u$ represents the unobserved variations.

\section{Descriptive Statistics}

\section{EMPIRICAL RESULT}

First the study shows the mean, standard deviation, minimum and maximum value for total 31 companies with 279 observation of the textile sector. Then we test the dataset against the assumptions of normal distribution to show what regression model fits our dataset best.

Table 2. Descriptive Statistics of Study

\begin{tabular}{|l|c|c|c|c|c|}
\hline \multicolumn{1}{|c|}{ Variables } & Obs & Mean & Std. Deviation & Min & Max \\
\hline ROA & 279 & 0.071 & 0.059 & -0.215 & 0.308 \\
\hline NPM & 279 & 0.034 & 0.243 & -3.147 & 0.745 \\
\hline TobinsQ & 279 & 1.824 & 2.645 & -1.353 & 25.007 \\
\hline Age & 279 & 20.871 & 10.781 & 4.000 & 57.000 \\
\hline In_Size & 279 & 21.492 & 1.071 & 18.622 & 23.602 \\
\hline DE & 279 & 0.692 & 0.768 & -1.672 & 4.796 \\
\hline DA & 279 & 0.332 & 0.287 & 0.000 & 2.517 \\
\hline CR & 279 & 2.049 & 2.374 & 0.084 & 14.673 \\
\hline Growth & 279 & 0.213 & 0.459 & -0.800 & 3.095 \\
\hline TATO & 279 & 0.761 & 0.639 & 0.065 & 4.104 \\
\hline EATC & 279 & 0.059 & 0.117 & -0.759 & 0.779 \\
\hline Taxation & 279 & 0.152 & 0.272 & -3.553 & 0.881 \\
\hline Ex_Gr & 279 & 0.113 & 0.116 & 0.002 & 0.4335 \\
\hline BdSize & 279 & 6.867 & 1.702 & 2 & 12 \\
\hline Real_GDP & 279 & 0.069 & 0.007 & 0.060 & 0.082 \\
\hline
\end{tabular}

Source: Author's Calculation 
Multicollinearity Test

Table 3. Result of Pearson Correlation Coefficient of Predictor Variables

\begin{tabular}{|l|c|c|c|c|c|c|c|c|c|c|c|c|}
\hline & Age & Size & DE & DA & CR & Growth & TATO & EATC & $\begin{array}{c}\text { Ta } \\
\mathbf{x}\end{array}$ & Ex_Gr & BdSize & GDP \\
\hline Age & 1.00 & & & & & & & & & & & \\
\hline Size & -0.42 & 1.00 & & & & & & & & & & \\
\hline DE & 0.09 & -0.02 & 1.00 & & & & & & & & & \\
\hline DA & 0.05 & -0.33 & 0.18 & 1.00 & & & & & & & & \\
\hline CR & -0.19 & 0.06 & -0.21 & -0.26 & 1.00 & & & & & & & \\
\hline Growth & -0.09 & 0.20 & -0.03 & -0.14 & 0.02 & 1.00 & & & & & & \\
\hline TATO & 0.24 & -0.43 & 0.06 & 0.06 & -0.18 & -0.14 & 1.00 & & & & & \\
\hline EATC & -0.28 & 0.20 & -0.19 & -0.31 & 0.21 & 0.19 & -0.14 & 1.00 & & & & \\
\hline Tax & 0.03 & -0.00 & -0.07 & -0.14 & -0.01 & 0.04 & 0.22 & 0.05 & $\begin{array}{c}1.0 \\
0\end{array}$ & & & \\
\hline Ex_Gr & -0.13 & -0.12 & 0.11 & 0.06 & -0.05 & 0.05 & 0.05 & 0.09 & $\begin{array}{c}0.0 \\
2\end{array}$ & 1.00 & & \\
\hline BdSize & 0.22 & 0.17 & -0.10 & 0.06 & -0.07 & 0.05 & -0.02 & -0.10 & $\begin{array}{c}- \\
0.0\end{array}$ & -0.10 & 1.00 & \\
\hline GDP & 0.21 & 0.15 & 0.02 & 0.10 & -0.01 & -0.01 & -0.08 & -0.22 & $\begin{array}{c}0.0 \\
5\end{array}$ & -0.26 & 0.06 & 1.00 \\
\hline
\end{tabular}

Source: Author's Calculation

The results shown in the table shows that there are no multicollinearity problems among the independent determinant variables selected in this study.

Table 4. Results of VIF Test

\begin{tabular}{|l|c|c|}
\hline \multicolumn{1}{|c|}{ Variables } & VIF & 1/VIF \\
\hline Ln_Size & 2.22 & 0.45 \\
\hline Age & 1.77 & 0.56 \\
\hline DA & 1.52 & 0.66 \\
\hline TATO & 1.38 & 0.72 \\
\hline Real_GDP & 1.31 & 0.77 \\
\hline EATC & 1.30 & 0.77 \\
\hline Ln_BdSize & 1.26 & 0.79 \\
\hline CR & 1.22 & 0.82 \\
\hline DE & 1.18 & 0.85 \\
\hline Ex_Gr & 1.14 & 0.88 \\
\hline Taxation & 1.10 & 0.91 \\
\hline Growth & 1.08 & 0.92 \\
\hline Mean & 1.37 & \\
\hline
\end{tabular}

Source: Author's Calculation

The VIF value for the selected variables that are tested in this paper is 1.37 on an average which indicates that the multicollinearity problems do not exist in this model. 


\section{Heteroscedasticity Test}

Table 5. Results of Heteroscedasticity Test

\begin{tabular}{|l|c|c|c|}
\hline \multicolumn{4}{|c|}{ Breusch Pagan /Cook-Weisberg test for heteroscedasticity } \\
\hline \multicolumn{1}{|c|}{ Model } & Chi2(1) & Prob>Chi2 & Presence of Heteroscedasticity \\
\hline Model 1-ROA & 11.33 & $0.00^{* * *}$ & YES \\
\hline Model 2-Tobin's Q & 86.29 & $0.00 * * *$ & YES \\
\hline
\end{tabular}

Note: * represents significance at $10 \%$ level, $* *$ represents significance at $5 \%$ level and $* * *$ represents significance at $1 \%$ level.

Source: Author's Calculation

The table shows the summary of Breusch-Pagan test.

\section{Autocorrelation Test}

Table 6. Results of Autocorrelation Test

\begin{tabular}{|l|c|c|c|}
\hline \multicolumn{4}{|c|}{ Wooldridge test for autocorrelation in panel data } \\
\hline \multicolumn{1}{|c|}{ Model } & Chi2(1) & Prob>Chi2 & Presence of Autocorrelation \\
\hline Model 1-ROA & 3.428 & $0.0740^{*}$ & YES \\
\hline Model 2-Tobins Q & 24.133 & $0.0000^{* * *}$ & YES \\
\hline
\end{tabular}

Note: * represents significance at $10 \%$ level, $* *$ represents significance at $5 \%$ level and $* * *$ represents significance at $1 \%$ level.

Source: Author's Calculation

Table shows the result of autocorrelation test for the model of this study using Wooldridge et al. (1995) test.

\section{Test for Cross Sectional Dependency}

To see whether our model suffer from cross-sectional dependency, the xtcsd command in STATA has been used following the methodology of Pesaran (2004) and Friedman (1937).

Table 7. Results of Test for Cross Sectional Dependency

\begin{tabular}{|l|c|c|c|c|}
\hline \multicolumn{1}{|c|}{ Model } & $\begin{array}{c}\text { Pesaran's } \\
\text { value }\end{array}$ & $\begin{array}{c}\text { Friedman } \\
\text { 's Value }\end{array}$ & $\begin{array}{c}\text { Avg. value of Off- } \\
\text { diagonal elements (abs) }\end{array}$ & Cross-Sectional Dependency \\
\hline Model 1-ROTA & -1.144 & 4.757 & 0.37 & YES $^{1}$ \\
\hline Model 3-Tobin's Q & $2.542^{* * *}$ & 16.80 & 0.38 & YES $^{2}$ \\
\hline
\end{tabular}

Sour Note: $1 \& 2$ represents that Pesaran's value and Friedman's value are ambiguous in terms of direction in which case the average off-diagonal value should be used as parameter. As off-diagonal value is greater than 0.25 , so Model ROTA and Tobin's $Q$ have considered to have cross sectional dependency.

Source: Author's Calculation

Table shows the result of pesaran's test for cross-sectional dependency. The results clearly show that at a $10 \%$ significance level, two of these models suffer from cross-sectional dependency.

\section{Hausman Test}

To choose whether we should go with random effect or fixed effect model, the Hausman (1978) test is needed to be run. The null hypothesis of the test states that random effect should be used. The null hypothesis can be rejected at the significance level of 5\%. 
Table 8. Results of Hausman Test

\begin{tabular}{|l|c|c|c|}
\hline \multicolumn{1}{|c|}{ Model } & Chi2(9) & P value & Decision \\
\hline Model 1-ROA & 51.49 & $0.0000 * * *$ & Fixed Effect Model \\
\hline Model 2-Tobins Q & 16.06 & 0.1884 & Random Effect Model \\
\hline
\end{tabular}

Note: * represents significance at $10 \%$ level, $* *$ represents significance at $5 \%$ level and $* * *$ represents significance at $1 \%$ level.

Source: Author's Calculation

As it is found that there is heteroscedasticity problem associated with each of the model in this study and the two model is suffering from serial correlation problem among error terms, the results generated from FE or RE model cannot be taken as utopia and unbiased. So, the model must be corrected for these problems in data set. Hence, the model selected for our study is PCSE model that is said to improve the robustness.

\section{Panel Corrected Standard Error (PCSE) Model}

PCSE model shows improved result when the dataset is balanced which is in agreement with our study

Table 9. Summary of Prais-Winston Linear Regression PCSE Analysis for Model $1 \& 2$

\begin{tabular}{|c|c|c|c|c|c|c|}
\hline \multirow{2}{*}{ Variables } & \multicolumn{3}{|c|}{ Model 1-ROTA } & \multicolumn{3}{|c|}{ Model 2-Tobin's Q } \\
\hline & Coef. & $\mathbf{Z}$ & $\mathbf{P}>|\mathbf{z}|$ & Coef. & $\mathbf{Z}$ & \begin{tabular}{l|l|}
$\mathbf{P}>\mid \mathbf{z}$ \\
\end{tabular} \\
\hline \multicolumn{7}{|c|}{ Firm-Specific factors } \\
\hline Age & $\underline{-0.01}$ & -6.39 & $0.00 * * *$ & 0.02 & 1.73 & $0.08^{*}$ \\
\hline Ln_Size & $\underline{-0.01}$ & -0.88 & 0.38 & -0.30 & -3.19 & $0.00 * * *$ \\
\hline DE & 0.03 & 5.3 & 0.00 *** & $\underline{-0.17}$ & -2.02 & $0.04 * *$ \\
\hline DA & $\underline{-0.06}$ & -3.26 & $0.00 * * *$ & 0.35 & 1.20 & 0.23 \\
\hline $\mathbf{C R}$ & $\underline{-0.01}$ & -1.46 & 0.14 & 0.00 & 0.09 & 0.93 \\
\hline Growth & $\underline{-0.01}$ & -3.16 & $0.00 * * *$ & -0.15 & -2.38 & $0.02 * *$ \\
\hline TATO & 0.04 & 5.8 & 0.00 *** & 0.11 & 0.69 & 0.49 \\
\hline EATC & 0.17 & 5.65 & $0.00 * * *$ & 1.31 & 2.33 & $0.02 * *$ \\
\hline Ln Bd Size & 0.01 & 0.3 & 0.76 & 0.34 & 2.05 & $0.04 * *$ \\
\hline \multicolumn{7}{|c|}{ Macro-economic Factors } \\
\hline Taxation & 0.01 & 0.3 & 0.77 & $\underline{-0.01}$ & -0.19 & 0.85 \\
\hline Ex_Growth & 0.27 & 2.03 & $0.04 * *$ & 8.00 & 2.60 & $0.01 * * *$ \\
\hline GDP & $\underline{-0.11}$ & -0.4 & 0.69 & 5.52 & 0.81 & 0.42 \\
\hline Constant & 0.15 & 2.05 & $0.04 * *$ & 6.19 & 2.81 & $0.01 * * *$ \\
\hline $\mathrm{R}-\mathrm{Sq}$ & \multicolumn{3}{|c|}{0.73} & \multicolumn{3}{|c|}{0.43} \\
\hline $\mathrm{Chi}^{2}$ & \multicolumn{3}{|c|}{230.99} & \multicolumn{3}{|c|}{63.91} \\
\hline Prob>Chi2 & \multicolumn{3}{|c|}{0.0000} & \multicolumn{3}{|c|}{0.0000} \\
\hline
\end{tabular}

Note: * represents significance at $10 \%$ level, $* *$ represents significance at $5 \%$ level and $* * *$ represents significance at $1 \%$ level. (Underline) represents wrong sign.

Source: Author's Calculation

Table shows the result of PCSE regression analysis for each of the two model. For model 1-ROA, the firm-specific factors i.e., size, Debt to equity (DE), asset turnover (TATO), cost efficiency measured by EATC, and board size have a positive impact on ROA and age of firm and 
size of the firm, DA, CR and Growth have a negative impact on net profit margin. However, among the independent firm-specific variables age, DE, DA, Growth, TATO and EATC have proved to be statistically significant. In terms of macro-economic variables, taxation and export growth have a positive impact on profitability and GDP growth has a negative impact on profitability. Among these variables, Export growth is being found to be statistically significant as $\mathrm{P}$ value is less than $5 \%$. The overall R2 is around 73\%. In addition, the model is found to be valid as the F-value is positively large and $\mathrm{p}$ value is less than $5 \%$. In other words, the goodness of fit of the model is pretty good in predicting the ROA of the textile sectors.

For Model 2-Tobin's Q, the PCSE model has a R2 value of 43\% implying that the goodness of the fit of this model is somewhat acceptable and the model is justifiable as well since it has a Fvalue of 63.91 and overall $\mathrm{p}$ value of lower than 5\%. According to the PCSE model, age, debt to asset (DA), CR, asset turnover (TATO), cost efficiency (EATC) and board size, GDP growth and export growth have a positive impact on market replacement value of profitability whereas size of the firm, Debt to Equity (DE), Growth and Taxation have a negative impact on profitability. Among the firm-specific variables, age, size of the firm, DE, growth, EATC, board size is found to be significant. Among the macro-specific variables, only export growth is found to be statistically significant.

\section{COMPARISON OF STUDY RESULTS WITH PREVIOUS WORKS}

According to WTO, Bangladesh holds the 3rd position among the top 10 exporters of clothing in 2019. China holds the 1st position in that list. India and Pakistan also took their position in that list too. A comparison of our result with those of previous literature is shown below.

Table 10. Comparison of the Study with Previous Literatures

\begin{tabular}{|l|c|c|c|c|}
\hline \multicolumn{6}{|c|}{ Comparison of results (Accounting measures of Profitability) } \\
\hline \multicolumn{1}{|c|}{ Variable } & $\begin{array}{c}\text { Expected } \\
\text { Sign }\end{array}$ & $\begin{array}{c}\text { Textile sector } \\
\text { of Bangladesh }\end{array}$ & $\begin{array}{c}\text { Previous literature } \\
\text { (Sign \& significance) }\end{array}$ & $\begin{array}{c}\text { Countries and sectors on the study } \\
\text { has been conducted }\end{array}$ \\
\hline \multicolumn{5}{|c|}{ Firm-Specific factors } \\
\hline Age & + & $(-) \sqrt{ }$ & $\begin{array}{c}\text { Positive; Significant } \\
\text { Negative; Significant }\end{array}$ & $\begin{array}{c}\text { Slovak, Metallurgic (2020) } \\
\text { Bangladesh, Textile (2020) }\end{array}$ \\
\hline Size & + & $(-) \times$ & $\begin{array}{c}\text { Negative; Significant } \\
\text { Positive; Significant }\end{array}$ & $\begin{array}{c}\text { Pakistan, Textile (2020) } \\
\text { China, Agricultural (2020) }\end{array}$ \\
\hline DE & $-/+$ & $(+) \sqrt{ }$ & $\begin{array}{c}\text { Negative; Significant } \\
\text { Positive; Significant }\end{array}$ & $\begin{array}{c}\text { Pakistan, Textile (2020) } \\
\text { India, Textile (2019) }\end{array}$ \\
\hline DA & $-/+$ & $(-) \sqrt{ }$ & $\begin{array}{c}\text { Negative; Insignificant } \\
\text { Negative; Insignificant }\end{array}$ & $\begin{array}{c}\text { Pakistan, Textile (2020) } \\
\text { China, Agricultural (2020) }\end{array}$ \\
\hline CR & + & $(-) \times$ & $\begin{array}{c}\text { Positive; Insignificant } \\
\text { Positive; Significant } \\
\text { Positive; Significant }\end{array}$ & $\begin{array}{c}\text { China, Agricultural (2020) } \\
\text { Slovak, Metallurgic (2020) } \\
\text { India, Textile (2019) }\end{array}$ \\
\hline Growth & + & $(-) \sqrt{ }$ & Positive; Significant & Pakistan, Textile (2020) \\
\hline TATO & + & $(+) \sqrt{ }$ & $\begin{array}{c}\text { Negative; insignificant } \\
\text { Negative; Insignificant }\end{array}$ & $\begin{array}{c}\text { Pakistan, Textile (2020) } \\
\text { India, Textile (2019) }\end{array}$ \\
\hline EATC & + & $(+) \sqrt{ }$ & Positive; Significant & Slovak, Metallurgic (2020) \\
\hline Board Size & + & $(+) \times$ & Negative; Insignificant & Portugal, Manufacturing (2019) \\
\hline
\end{tabular}




\begin{tabular}{|l|c|c|c|c|}
\hline \multicolumn{5}{|c|}{ Macro-economic factors } \\
\hline Taxation & + & $(+) \times$ & Positive; Insignificant & Pakistan, Textile (2020) \\
\hline Ex_Growth & + & $(+) \sqrt{ }$ & Positive; Significant & Pakistan, Textile (2020) \\
\hline GDP & + & $(-) \times$ & $\begin{array}{c}\text { Positive; Insignificant } \\
\text { Positive; Insignificant }\end{array}$ & $\begin{array}{c}\text { China, Agricultural (2020) } \\
\text { Portugal, Manufacturing (2019) }\end{array}$ \\
\hline
\end{tabular}

\section{Findings}

\section{FINDINGS AND DISCUSSIONS}

This section is divided into two parts. First the study presents the findings of individual model in terms of PCSE regression analysis as this model corrects all the diagnostic issues with the dataset. Later the overall findings of the paper are discussed in this section. From the analysis it is lucid that there are a number of firm-specific and macro-specific factors that influence firm performance. The findings of individual model are disclosed below.

Table 11. Summary Result of Model 1- ROA

\begin{tabular}{|l|c|c|c|}
\hline \multirow{2}{*}{ Variable } & \multirow{2}{*}{ Expected Sign } & \multicolumn{2}{c|}{ PCSE Model } \\
\cline { 3 - 4 } & \multicolumn{2}{c|}{ Firm-Specific factors } & Significance \\
\hline Age & + & - & $\sqrt{ }$ \\
\hline Ln_Size & + & - & $\times$ \\
\hline DE & $-/+$ & + & $\sqrt{ }$ \\
\hline DA & $-/+$ & - & $\times$ \\
\hline CR & + & - & $\sqrt{ }$ \\
\hline Growth & + & + & $\sqrt{ }$ \\
\hline TATO & + & + & $\times$ \\
\hline EATC & + & + & $\times$ \\
\hline Board Size & + & + & $\sqrt{ }$ \\
\hline \multicolumn{7}{|c|}{ Macro-economic factors } \\
\hline Taxation & + & + & $\times$ \\
\hline Ex_Growth & + & + & \\
\hline GDP & + & & \\
\hline
\end{tabular}

In the first model, ROA is taken as a proxy for accounting profitability in textile sector. Our analysis found that in textile sector, as firm is aging, their performance is retrograding significantly. In our study, it is found that as size of the firm is increasing, firm performance is degrading but the result is not significant. The relationship between capital structure and profitability can be both positive and negative supported by two classes of theories: trade-off theory and pecking order theory. In our study, it is found that debt to equity is positively and significantly related to profitability. It can be supported by the fact that mean debt to equity ratio of textile sector is around $69 \%$ and the firms are getting the tax benefit due to this higher ratio. Liquidity $\mathrm{CR}$ is found to be negatively related to profitability but the result is insignificant. As the mean CR ratio of textile firm is 2.05 , it can be concluded that excessive capital is being unutilized 
bringing down the profitability. Another paradoxical relationship found is between growth of assets and profitability at a significant level.

In terms of macro-economic factors, taxation and export growth are found to be positively related to ROA. It agrees with the expected sign of the variables but only Export growth is found to be significant in result. GDP growth rate is found to be negatively but insignificantly related to profitability.

Table 12. Summary Result of Model 2- Tobin's Q

\begin{tabular}{|c|c|c|c|}
\hline \multirow[t]{2}{*}{ Variable } & \multirow[t]{2}{*}{ Expected Sign } & \multicolumn{2}{|c|}{ PCSE Model } \\
\hline & & Actual Sign & Significance \\
\hline \multicolumn{4}{|c|}{ Firm-Specific factors } \\
\hline Age & + & + & $\sqrt{ }$ \\
\hline$\overline{L n \_S i z e}$ & + & - & $\sqrt{ }$ \\
\hline DE & $-/+$ & - & $\sqrt{ }$ \\
\hline DA & $-1+$ & + & $x$ \\
\hline CR & + & + & $x$ \\
\hline Growth & + & - & $\sqrt{ }$ \\
\hline TATO & + & + & $x$ \\
\hline EATC & + & + & $\sqrt{ }$ \\
\hline Board Size & + & + & $\sqrt{ }$ \\
\hline \multicolumn{4}{|c|}{ Macro-economic factors } \\
\hline Taxation & + & - & $x$ \\
\hline Ex_Growth & + & + & $\sqrt{ }$ \\
\hline GDP & + & + & $x$ \\
\hline
\end{tabular}

Model 2-Tobin's Q represents profitability in terms of market performance and its replacement cost. It can be seen from the table that; age of the firm has a positive and significant impact on firm market performance of textile sector. Size of the firm and profitability is found to have a significantly negative paradoxical relationship with firm market performance. It is the same as the result found when profitability was measured by ROA. DE is found to have a negative significant impact on firm's market replacement value. Debt to asset ratio shows a paradoxical relationship with firm performance but it was insignificant. Liquidity $C R$ is found to be insignificant and positively related to firm value. Growth of asset is found to be negatively and significantly related to firm performance. TATO, EATC and board size are found to be positively and significantly related to firm performance just like when regressed with ROA as well.

In terms of macro-economic factors, export growth and GDP are found to have a positive impact on firm market performance while taxation found to be negatively related to profitability. Only export growth is found to be significant. It agrees with the expected sign as well as the sign found from Model 1-ROA.

\section{Discussion of Findings}

Hence, the overall findings of this study are that both firm-specific and macro-economic variables have a significant impact on profitability of the Textile sectors in terms of the different measures of profitability. However, their impact on profitability rest on which variable has been selected as 
a proxy to measure profitability. Specifically, asset turnover (TATO), cost efficiency (EATC) and Export growth (Ln.ex_growth) are found to be the most significant and influential factor to determine the firm's profitability. TATO, EATC and export growth are inferred to be positively related no matter which measures of profitability is selected. Age of the firm is another significant variable impacting firm's performance. Yet the direction of its relationship with profitability depends on from which point of view profitability is being measured. Size of the asset base of the firms is found to be negatively related to profitability inferring that increased asset size is not being effectively utilized to generate profits as well. Another significant variable, Growth, has proved to be negatively related to profitability suggesting that within textile sector, business performance is retrograding with age implying the lower growth rates for these firms. It urges textile firms need to be more efficient in terms of technology and labor utilization. Otherwise, profitability will see a downward trend despite its asset growth. Board size has a positive impact on profitability when measured by accounting book value terms (ROA) or market value measures (Tobin's Q). Though it does not show significant result in terms of ROA, still it can be implied that the larger size of the board is skeptical in performing its monitoring role actively enhancing its profitability. Taxation has a positive impact on profitability in terms of book value profitability. It implies that, though having an insignificant relationship, firms paying a moderate level of tax accomplish greater profitability conforming to the trade-off theory of the higher the tax rate, the lower the debt costs. Lastly, debt to equity (DE) is found to have a positive relationship with profitability in terms of ROA as the dependent variables. It implies that the trade-off theory holds true in this case. Lastly, other than export growth, no macro-economic factors seem to provide a significant and consistent relationship with profitability.

\section{CONCLUSION AND IMPLICATIONS}

This study examines the firm-specific factors and macro-economic determinants of firm profitability of textile sector of Bangladesh. The results using the PCSE model suggest that the determinants of financial performance change depending on the variable taken as a proxy of firm profitability. Since managers and investors constitute varying interest, the relative strengths of any explanatory variables on both of these proxies of firm performance must be known.

For the first model, ROA was used to measure firm performance. As growth and age of the firm has a negative paradoxical relationship with profitability, it advises that policymakers and management body of the firms of textile sectors must manage their firms more efficiently by introducing technological equipment so that the increased assets size and their experience in terms of increased leads to productivity instead of declining it. Moreover, policymakers should continue to give rebate and incentives so that our RMG products are most welcome in other countries and the textile industry remains competitive.

Our second model incorporates Tobin's Q as firm's profitability. Leverage and size of the firm have negative impact on profitability. It implies that investors prefer growth of firm be equipped with subsequent profitable investment instead of underutilization and lower level of financial leverage. So, managers must look into this issue to increase profitability. In terms of macro-economic factors, only export growth is found to have a significant positive impact on profitability urging the policymakers to support export growth.

This research may contribute to a wide range of stakeholders such as managers, investors, regulators, banks etc. However, this study has some limitations. This study can include only 31 firms in its sample as market of our country is still small. Moreover, there are some other variables 
that could have influence on firm performance but were not considered in this study such as R\&D intensity, innovation etc. This also gives a scope for further research.

\section{REFERENCES}

Antoun, R., Coskun, A., \& Georgievski, B., (2018). Determinants of financial performance of banks in Central and Eastern Europe. Business and Economic Horizons, 14(3), 513-529.

Abbas, A., Z. Bashir, S., Manzoor \& Akram M. N. (2013). Determinants of firm's financial performance: an empirical study on textile sector of Pakistan. Business Economic Research, 3(2), 76-84.

Ahmad, W., Ahmed, T., \& Shabbir, G. (2015). Determinants of textile firms' profitability in Pakistan. Forman Journal of Economic Studies, 11, 87-101.

Asimakopoulus, I., Samitas, A., \& Papadogonas, T. (2009). Firm-specific and economy wide determinants of firm profitability: Greek evidence using panel data. Managerial Finance, 35(11), 930-939.

Barney, J.B. (1991). Firm resources and sustained and sustained competitive advantage. Journal of Management, 17(1), 99-120.

Blažková, I., \& Dvouletý, O. (2018). The causes of firm performance variation in the Czech food processing industry in the context of the outlier effect. Management Research Review, 41(8), 968-986.

Blažková, I., \& Dvouletý, O. (2019). Investigating the differences in entrepreneurial success through the firm-specific factors: Microeconomic evidence from the Czech food industry. Journal of Entrepreneurship in Emerging Economies, 11(2), 154-176.

Bayaraa, B. (2017). Financial performance determinants of organizations: The case of Mongolian companies. Journal of Competitiveness, 9(3) 22-33.

Bhutta, N. T., \& Hasan, A. (2013). Impact of firm specific factors on profitability of firms in food sector. Open Journal of Accounting, 2, 19-25.

Chhapra, Umer, I., \& Muhammad, A. (2012). Determinants of capital structuring: an empirical study of growth and financing behavior of firms of textile sector in Pakistan. MPRA Paper 51068, University Library of Munich, Germany.

Coad A., Segarra A., \& Teruel M. (2013). Like milk or wine: Does firm performance improve with age?. Structural Change and Economic Dynamics, 24(1), 173-189.

Cowling, M., Liu, W., \& Zhang, N. (2018). Did firm age, experience, and access to finance count? SME performance after the global financial crisis. Journal of Evolutionary Economics, 28(1), 77-100. 
Chowdhury, A., \& Amin, M.M. (2007). Working capital management practiced in pharmaceutical companies listed in Dhaka stock exchange. BRAC University Journal, 4(2), 75-86.

Chhibber, P.K., \& Majumder, K.K. (1999). Foreign ownershipand profitability: Property rights, control, and the performance of firms in Indian industry. Journal of Law and Economics, 42(1), 209-238.

Chavez R., Yu W., Jacobs M. A., \& Feng, M. (2017). Manufacturing capability and organizational performance: The role of entrepreneurial orientation. International Journal of Production Economics, 184, 33-46. https://doi.org/10.1016/j.ijpe.2016.10.028

Chung, H. K., \& Pruitt, W. S. (1994). A simple approximation of Tobin's Q. Financial Management, 23(3), 70-74.

Dakić, S., Mijić, K., \& Jakšić, D. (2019). Multiple regression approach to modelling determinants of business success based on financial statement: Evidence from food processing companies in the Republic of Serbia. Custos e Agronegocio on Line, 15(4), 485-501.

Daily, C.M., Dalton, D.R., \& Cannella, A.A. (2003). Corporate governance: decades of dialogue and data. The Academy of Management Review, 28(3), 371-382.

Drobetz, W., Schillhofer, A., \& Zimmermann, H. (2004). Corporate governance and expected stock returns: evidence from Germany. European Financial Management, 10(2), 267-293.

Fiala, R., Hedija, V., Dvorak, J., \& Jansky, J. (2020). Are profitable firms also financially healthy? Empirical evidence for pig-breeding sector. Custos e Agronegocio on Line, 16(1), 173-201.

Friedman, M. (1937). The use of ranks to avoid the assumption of normality implicit in the analysis of variance. Journal of the American Statistical Association, 32, 675-701.

Gan, C., Lee, M., Yong, H.H.A., \& Zhang, J. (2006). Macroeconomic variables and stock market interactions: New Zealand evidence. Investment Management and Financial Innovation, 3(4), 80-101.

Goddard, J., Tavakoli, M., \& Wilson J.O.S. (2005). Determinants of profitability in European manufacturing and services: Evidence from a dynamic panel model. Applied Financial Economics, 15(18), 1269-1282.

Glen, S. (2021). Ample Size in Statistics (How to Find it): Excel, Cochran's Formula, and General Tips" From StatisticsHowTo.com: Elementary Statistics for the rest of us! Retrieved from https://www.statisticshowto.com/probability-and-statistics/find-sample-size/

Glancey, K. (1998). Determinants of growth and profitability in small entrepreneurial firms. International Journal of Entrepreneurial Behavior and Research, 4(1), 18-27. 
Guest, P. M. (2009). The impact of board size on firm performance: evidence from the UK. The European Journal of Finance, 15(4), 385-404.

Hintošová, A. B., Bobenič T., Hajduová, Z., \& Szajt M. (2020). The influence of firm-specific factors on firms' performance. Polish Journal of Management Studies, 21(2), 115-128.

Hult, G.T.M., Ketchen, D.J., Griffith, D.A., Chabowski, B. R., Hamman, M.K., Dykes, B.J., Pollitte, W.A., \& Cavusgil, S.T. (2008). An assessment of the measurement of performance in international business research. Journal of International Business Studies, 39(6), 10641080 .

Hausman, J. A. (1978). Specification tests in econometrics. Econometrica, 46, 1251-1271. https://doi.org/10.2307/1913827

Hanggraeni, D., Slusarczyk B., Sulung L.A.K., \& Subroto A., (2019). The Impact of internal, external and enterprise risk management on the performance of micro, small and medium enterprises. Sustainability, 11(7), 2172. https://doi.org/10.3390/su11072172

Hermelo, F. D., \& Vassolo, R. (2007). The determinants of firm's growth: an empirical examination. Abante, Escuela de Administracion Pontificia Universidad Católica de Chile, $10(1), 3-20$.

Islam, M.S., \& Khan, S. (2019). The determinants of profitability of the pharmaceutical industry of Bangladesh: a random effect analysis. International Journal of Financial Research, 10(2), 68-74.

Jelena, A., Kristina, M., Vera, M., \& Branimir, K. (2018). The modelling factors of agricultural companies performances. Custos e Agronegocio on Line, 14(4), 223-240.

Kalam, A., \& Utsho, M. I. (2020). Effects of firm specific factors on profitability of non-bank financial institutions in Bangladesh: evidenced from Dhaka Stock Exchange (DSE). International Journal of Science and Business, 4(11), 1-13.

Khaled, A. J., \& Samman, H. A. (2015). Determinants of profitability: evidence from industrial companies listed on Muscat securities market. Review of European Studies, 7(11), 303311.

Kosmidou, K. (2008). The determinants of banks' profits in Greece during the period of EU financial integration. Management Finance, 34(3), 146-159.

Kennedy, P. (2003). A Guide to Econometrics. MIT Press, Cambridge.

Kuntluru, S., Muppani, V.R., \& Khan, A.M. (2008). Financial performance of foreign and domestic owned companies in India. Journal of Asia-Pacific Business, 9(1), 28-54. 
Kumari, R., \& Kumar, N. (2018). Determinants of firm performance: A conceptual analysis. Pacific Business Review International, 10(11), 133-140.

Lujing Liu., Jian Xu., \& Yue Shang. (2020). Determining factors of financial performance of agricultural listed companies of China. Custos e Agronegocio, 16(4), 297-314.

Mcgahan, A.M., \& Porter, M. E. (2002). What do we know about variance in accounting profitability? Management Science, 48(7), 834-851.

Marcelo, J.L., Quirós, M., \& Lisboa, I. (2014). The impact of family control on firm performance: evidence from Portugal and Spain. Journal of Family Business Strategy, 5(2), 156-168.

Majumdar, S., \& Chhibber, P. (1999). Capital structure and performance: evidence from a transition economy on an aspect of corporate governance. Public Choice, 98, 287-305. https://doi.org/10.1023/A:1018355127454.

Mijić, K., Zekić, S., Jakšić, D., \& Vuković, B. (2014). Meat industry in Serbia: performance analysis of meat-processing and livestock companies. Custos e Agronegocio On Line, $10(3), 124-144$.

Nunes M. P. J., Serrasqueiro Z. M., \& Sequeira T. N., (2009). Profitability in Portuguese service industries: A panel data approach. Service Industries Journal, 29(5), 693-707.

Nakatani R. (2019). Firm performance and corporate finance in New Zealand. Applied Economics Letters, 26(13), 1118-1124.

Nanda, S., \& Panda, A. K. (2018). The determinants of corporate profitability: an investigation of Indian manufacturing firms. International Journal of Emerging Markets, 13(1), 66-86.

Pervan, M., Curak, M., \& Kramaric, T. P. (2018). The influence of industry characteristics and dynamic capabilities on firms' profitability. International Journal of Financial Studies, 6(4), 1-19.

Porter, M.E. (1980), Competitive Strategy. The Free Press, New York.

Pathirawasam, C. (2011). Internal factors which determine financial performance of firms: with special reference to ownership concentration. Retrieved from https://www.slu.cz/opf/cz/informace/acta-academica-karviniensia/casopisy-aak/aakrocnik-2013/docs-2-2013/Pathirawasam.pdf/

Pratheepan, T. (2014). A panel data analysis of profitability determinants: Empirical results from Sri Lankan manufacturing companies. International Journal of Economics, Commerce and Management, 2(12), 1-9.

Pesaran, M. H. (2004). General diagnostic tests for cross section dependence in panels. Cambridge working papers in economics 0435, Faculty of Economics, University of Cambridge. 
Rumelt, R.P. (1991). How much does industry matter?. Strategic Management Journal, 12(3), 167-185.

Schumacher, S., \& Boland, M. (2005). The effects of industry and firm resources on profitability in the food economy. Agribusiness, 21(1), 97-108.

Stierwald, A. (2010). Determinants of profitability: An analysis of large Australian firms. Retrieved

from https://melbourneinstitute.unimelb.edu.au/downloads/working_paper_series/wp2010n03. pdf

Singh, K., Misra, M., Kumar, M., \& Tiwari, V. (2019). A study on the determinants of financial performance of US agricultural cooperatives. Journal of Business Economics and Management, 20(4), 633-647.

Singh, S.,Tabassum, N., Darwish, T. K., \& Batsakis, G. (2017). Corporate governance and Tobin's $\mathrm{Q}$ as a measure of organizational performance. British journal of management, 29(4), 120. https://doi.org/10.1111/1467-8551.12237

Ullah, A., Pinglu, C., Ullah, S., Zaman, M., \& Hashmi, S. H. (2020). The nexus between capital structure, firm-specific factors, macroeconomic factors and financial performance in the textile sector of Pakistan. Heliyon, 6(4), 741-755. https://doi.org/10.1016/j.heliyon.2020.e04741.

Vieira E. S., Neves M. E., \& Dias A. G. (2019). Determinants of Portuguese firms` financial performance: A panel data evidence. International Journal of Productivity and Performance Management, 68(7), 1323-1342.

Wooldridge, J. M. (1995). Score diagnostics for linear models estimated by two stages least squares. In C. R. Rao, G. S. Maddala, P. C. B. Phillips, \& T. N. Srinivasan (Eds.), Advances in Econometrics and Quantitative Economics (pp. 66-87). Oxford: Blackwell.

Yameen, M., Farhan, N., \& Tabash, M. (2019). The impact of liquidity on firms' performance: empirical investigation from indian pharmaceutical companies. Academic journal of interdisciplinary studies, 8(3), 212-220. https://doi.org/10.36941/ajis-2019-0019

Zainudin R., Mahdzan, N. S. A., \& Leong, E. S. (2018). Firm-specific internal determinants of profitability performance: An exploratory study of selected life insurance firms in Asia. International Journal of Asia Business Studies, 12(4), 533-550.

\section{APPENDICES}

\section{List of textile companies}

\begin{tabular}{|l|l|l|l|}
\hline $\begin{array}{c}\text { Serial } \\
\text { No }\end{array}$ & \multicolumn{1}{|c|}{ Name } & $\begin{array}{c}\text { Serial } \\
\text { No }\end{array}$ & Name \\
\hline 1 & Alhaj Textile Mills Limited & 17 & Paramount Textile Limited \\
\hline
\end{tabular}




\begin{tabular}{|l|l|l|l|}
\hline 2 & Alltex Industries Limited & 18 & Rahim Textile Mills Limited \\
\hline 3 & Anlimayarn Dyeing Limited & 19 & Regent Textile Mills Limited \\
\hline 4 & Apex Spinning and Knitting Mills Limited & 20 & R.N. Spinning Mills Limited \\
\hline 5 & Argon Denims Limited & 21 & Safko Spinning Mills limited \\
\hline 6 & Dragon Sweater and Spinning Limited & 22 & Saiham Cotton Mills Limited \\
\hline 7 & Dulamia Cotton Spinning Mills Limited & 23 & Saiham Textile Mills Limited \\
\hline 8 & Desh Garments Limited & 24 & Shasha Denims Limited \\
\hline 9 & Envoy Textiles Limited & 25 & Simtex Industries Limited \\
\hline 10 & H. R. Textile Mills Limited & 26 & Sonargaon Textiles Limited \\
\hline 11 & Maksons Spinning Mills Limited & 27 & Square Textiles Limited \\
\hline 12 & Malek Spinning Mills Limited & 28 & Stylecraft Limited \\
\hline 13 & Matin Spinning Mills Limited & 29 & Tosrifa Industries Limited \\
\hline 14 & Metro Spinning Limited & 30 & Zaheen Spinning Limited \\
\hline 15 & Mozaffar Hossain Spinning Mills Limited & 31 & Zahintex Industries Limited \\
\hline 16 & Prime Textile Spinning Mills Limited & & \\
& & & \\
\hline
\end{tabular}

\section{Copyrights}

Copyright for this article is retained by the author(s), with first publication rights granted to the journal. This is an open-access article distributed under the terms and conditions of the Creative Commons Attribution license (https://creativecommons.org/licenses/by/4.0/). 